NASA/TM-2001-210944

\title{
Thermal Processing Effects on the Adhesive Strength of PS304 High Temperature Solid Lubricant Coatings
}

Christopher DellaCorte and Brian J. Edmonds

Glenn Research Center, Cleveland, Ohio

Patricia A. Benoy

St. Louis University, St. Louis, Missouri 
Since its founding, NASA has been dedicated to the advancement of aeronautics and space science. The NASA Scientific and Technical Information (STI) Program Office plays a key part in helping NASA maintain this important role.

The NASA STI Program Office is operated by Langley Research Center, the Lead Center for NASA's scientific and technical information. The NASA STI Program Office provides access to the NASA STI Database, the largest collection of aeronautical and space science STI in the world. The Program Office is also NASA's institutional mechanism for disseminating the results of its research and development activities. These results are published by NASA in the NASA STI Report Series, which includes the following report types:

- TECHNICAL PUBLICATION. Reports of completed research or a major significant phase of research that present the results of NASA programs and include extensive data or theoretical analysis. Includes compilations of significant scientific and technical data and information deemed to be of continuing reference value. NASA's counterpart of peerreviewed formal professional papers but has less stringent limitations on manuscript length and extent of graphic presentations.

- TECHNICAL MEMORANDUM. Scientific and technical findings that are preliminary or of specialized interest, e.g., quick release reports, working papers, and bibliographies that contain minimal annotation. Does not contain extensive analysis.

- CONTRACTOR REPORT. Scientific and technical findings by NASA-sponsored contractors and grantees.
- CONFERENCE PUBLICATION. Collected papers from scientific and technical conferences, symposia, seminars, or other meetings sponsored or cosponsored by NASA.

- SPECIAL PUBLICATION. Scientific, technical, or historical information from NASA programs, projects, and missions, often concerned with subjects having substantial public interest.

- TECHNICAL TRANSLATION. Englishlanguage translations of foreign scientific and technical material pertinent to NASA's mission.

Specialized services that complement the STI Program Office's diverse offerings include creating custom thesauri, building customized data bases, organizing and publishing research results ... even providing videos.

For more information about the NASA STI Program Office, see the following:

- Access the NASA STI Program Home Page at http:/Www.sti.nasa.gov

- E-mail your question via the Internet to help@sti.nasa.gov

- Fax your question to the NASA Access Help Desk at 301-621-0134

- Telephone the NASA Access Help Desk at 301-621-0390

- Write to:

NASA Access Help Desk NASA Center for AeroSpace Information 7121 Standard Drive Hanover, MD 21076 
NASA/TM-2001-210944

\section{Thermal Processing Effects on the Adhesive Strength of PS304 High Temperature Solid Lubricant Coatings}

Christopher DellaCorte and Brian J. Edmonds

Glenn Research Center, Cleveland, Ohio

Patricia A. Benoy

St. Louis University, St. Louis, Missouri

National Aeronautics and

Space Administration

Glenn Research Center 


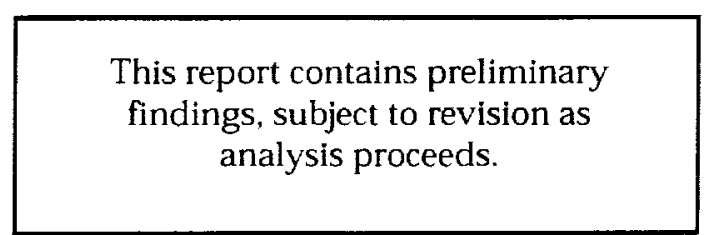

Available from

NASA Center for Aerospace Information 7121 Standard Drive

Hanover, MD 21076
National Technical Information Service 5285 Port Royal Road Springfield, VA 22100 


\title{
THERMAL PROCESSING EFFECTS ON THE ADHESIVE STRENGTH OF PS304 HIGH TEMPERATURE SOLID LUBRICANT COATINGS
}

\author{
Christopher DellaCorte and Brian J. Edmonds \\ National Aeronautics and Space Administration \\ Glenn Research Center \\ Cleveland, Ohio 44135 \\ Patricia A. Benoy \\ St. Louis University \\ St. Louis, Missouri 63103
}

SUMMARY

In this paper the effects of post deposition heat treatments on the cohesive and adhesive strength properties of PS304, a plasma sprayed nickel-chrome based, high temperature solid lubricant coating deposited on stainless steel, are studied. Plasma spray deposited coating samples were exposed in air at temperatures from 432 to $650^{\circ} \mathrm{C}$ for up to $500 \mathrm{hr}$ to promote residual stress relief, enhance particle to particle bonding and increase coating to substrate bond strength. Coating pull off strength was measured using a commercial adhesion tester that utilizes $13 \mathrm{~mm}$ diameter aluminum pull studs attached to the coating surface with epoxy. Pull off force was automatically recorded and converted to coating pull off strength. As deposited coating samples were also tested as a baseline.

The as-deposited (untreated) samples either delaminated at the coating-substrate interface or failed internally (cohesive failure) at about $17 \mathrm{MPa}$. Samples heat treated at temperatures above $540{ }^{\circ} \mathrm{C}$ for $100 \mathrm{hr}$ or at $600^{\circ} \mathrm{C}$ or above for more than $24 \mathrm{hr}$ exhibited strengths above $31 \mathrm{MPa}$, nearly a two fold increase. Coating failure occurred inside the body of the coating (cohesive failure) for nearly all of the heat-treated samples and only occasionally at the coating substrate interface (adhesive failure). Metallographic analyses of heat-treated coatings indicate that the Nickel-Chromium binder in the PS304 appears to have segregated into two phases, a high nickel matrix phase and a high chromium precipitated phase. Analysis of the precipitates indicates the presence of silicon, a constituent of a flow enhancing additive in the commercial $\mathrm{NiCr}$ powder. The exact nature and structure of the precipitate phase is not known. This microstructural change is believed to be partially responsible for the coating strength increase. Diffusion bonding between particles may also be playing a role. Increasing the heat treatment temperature, exposure time or both accelerate the heat treatment process. Preliminary measurements indicate that the heat treatment also results in a one time, permanent coating thickness increase of about 3 percent. Based upon these results, the incorporation of a heat treatment prior to final finishing has been incorporated in the application process of this coating technology.

\section{INTRODUCTION}

PS304 is a plasma sprayed, high temperature solid lubricant coating developed to reduce friction and wear of sliding contacts operating from below room temperature to over $750^{\circ} \mathrm{C}$ (refs. 1 to 4). PS304 is comprised of a nickel-chromium $(\mathrm{NiCr})$ matrix $(60 \mathrm{wt} \%)$ combined with chrome oxide $(20 \mathrm{wt} \%)$ as a hardening phase and the solid lubricant additives silver $(10 \mathrm{wt} \%)$ and barium fluoride/calcium fluoride eutectic $(10 \mathrm{wt} \%)$. For the PS304 composite coating, each constituent contributes functionality. For example, silver, a soft metal, provides low temperature lubrication while the fluorides provide high temperature lubrication. The chrome oxide acts as a thermochemically stable hardening phase. The $\mathrm{NiCr}$ matrix bonds the components to each other and the substrate. Since $\mathrm{NiCr}$ bonds well to candidate stainless steel and superalloy substrates the PS304 coating is routinely applied directly to the surface of parts needing lubrication without the use of intermediate bond coat layers. Figure 1 shows a typical cross-section photomicrograph of PS304.

Extensive development work has been conducted and reported on this composite coating. This work includes compositional tailoring for thermal expansion coefficient control (ref. 4), friction and wear testing (refs. 1 and 2) and coating performance as a start/stop shaft lubricant for foil air bearings (refs. 5 and 6). During the course of these studies it was observed that the coating undergoes a one-time dimensional change (coating thickness increase of a few percent) accompanied by an apparent strength (hardness) increase when exposed to moderate temperatures $\left(\sim 500^{\circ} \mathrm{C}\right)$ for long periods $(\sim 100 \mathrm{hr})$. Routine metallographic cross sections have 
shown evidence of a complex interfacial reaction layer between the coating and superalloy substrates as well as an apparent microstructural coarsening of the coating's matrix ( $\mathrm{NiCr}$ ) phase. Figure 2 shows such changes for a PS304 coated nickel based superalloy specimen exposed to $650^{\circ} \mathrm{C}$ in air for over $700 \mathrm{hr}$. These microstructural and interfacial changes do not appear to negatively affect coating performance but warrant further study.

Since coating adhesion can play a critical role in coating performance it has been selected for further investigation in the current work. Others have observed similar strengthening effects in $\mathrm{NiCr}$ based coatings following heat treatments but offer no explanation (ref. 7). It is believed that study of coating adhesion properties may provide insight into the phenomena described above and help establish processing parameters for more widespread coating implementation. The following sections describe the results of adhesion tests on PS304 coatings deposited on stainless steel prior to and after heat treatments in air at varying temperatures and durations. Stainless steel is the selected substrate because it is a likely coating substrate and is the shaft material being used in an Oil-Free turbocharger using PS304 (refs. 8 and 9).

The ultimate goals of this work are to develop a better understanding of the role of the heat treatment and to better identify and understand the mechanism(s) in action during thermal exposure. It is anticipated that the results will also be used to develop a preliminary heat treatment process for the PS304 coating to foster commercialization of this coating technology.

\section{TEST PROCEDURES AND APPARATUS}

\section{PS304 Coating and Deposition}

The PS304 coating is plasma spray deposited using conventional plasma spray procedures described fully in references 10 and 11. Briefly, a powder blend of the constituents in PS304 (shown in table I) is fed by a hopper into an argon gas stream and injected into an argon plasma in a plasma spray gun. The high temperature in the plasma gun melts the powder and accelerates it out of the gun nozzle. The molten powder then impinges onto the substrate where it "splats" and solidifies forming a thin, discontinuous coating. Multiple passes are applied to build up a thick $(\sim 350 \mu \mathrm{m})$ coating layer. Following deposition the coating is ground to achieve a smooth surface finish and the desired thickness. The deposition and solidification process occurs rapidly and often creates residual stresses in the coating. Figure 1 shows a representative cross-section photomicrograph of the PS304 coating deposited onto a stainless steel substrate. Table II shows selected properties and the composition of the stainless steel used in this work. PS304 coatings have a layered structure where each layer is the result of each coating pass. For PS304, $20 \mu \mathrm{m}$ of coating is deposited per pass and 10 to 20 passes are applied to build up a 250 to $350 \mu \mathrm{m}$ thick coating shown. As seen in the photomicrograph, the PS304 coating is a heterogeneous composite in which each constituent appears as a distinct phase.

\section{PULL/ADHESION TEST}

To evaluate coating strength, a commercial adhesion tester is used. This test hardware, shown schematically in figure 3 , consists of an aluminum pull stud which is glued to the coating surface, a pneumatic piston system for applying the pull of force and an electronic pressure controller/readout for measuring and recording the pull off pressure. The head of the pull stud is attached to the coating surface using a two part epoxy glue which is mixed, applied, air cured for about $8 \mathrm{hr}$ then oven cured at $75^{\circ} \mathrm{C}$ for an additional $24 \mathrm{hr}$ prior to pull testing. The epoxy has a rated strength of about $60 \mathrm{MPa}$ under ideal conditions and typically exceeds $12 \mathrm{MPa}$ when attached to the rough plasma spray coating. For reference, plasma sprayed coatings like PS304 that exhibit adhesion strength greater than $4 \mathrm{MPa}$ are usually considered acceptable for most tribological applications.

To conduct a test, a coated and glued specimen assembly is placed into the fixture shown previously in figure 3. The controller is started which gradually pressurizes the loading piston thereby increasing the applied pull force until it exceeds the strength of the coating or the epoxy bond. When the pull off force exceeds the strength the stub detaches from the sample and the test ends. A digital pressure readout on the controller displays the peak pressure applied during the test. It is recorded and converted to coating strength in MPa using a manufacturer's generated data sheet. Since nonuniform epoxy application, misaligned studs and surface irregularities present in the as-deposited PS304 samples can result in data scatter at least three repeat tests are done for each test condition. 
The samples can fail in one of three ways. If the coating to substrate bond is weakest the stud will pull off the sample removing the full coating and exposing the stainless steel substrate. If the bond is strong but the coating cohesive strength is low the stud will pull off the sample and remove some of the coating with failure occurring within the coating. Finally, if both the coating and its bond to the substrate are strong the stub will pull off the sample with failure occurring within the epoxy layer. By observing where failure occurs, coating properties (e.g., bond strength, apparent tensile strength etc.) and the effect of differing heat treatments can be assessed.

\section{COATING MICROSTRUCTURAL ANALYSES}

Selected coating samples were mounted in metallographic potting compound (epoxy) and prepared by conventional metallographic methods for analyses. Viewing the coating cross sections before and after thermal processing can lend insight into microstructural changes and their effects on strength. Both optical and Scanning Electron Microscopic (SEM) techniques were employed in this work. For SEM analyses, the samples were coated with a thin layer of gold to prevent charge build-up that can obscure the images.

\section{RESULTS AND DISCUSSIONS}

The PS304 exhibits a pull off strength of $17 \mathrm{MPa}$ in the as-deposited condition with no heat treatment. Failure occurs within the coating in a cohesive manner suggesting that the bond between the coating and the substrate is stronger than the coating itself. Coatings exposed to high temperatures for brief periods or moderate temperatures for long periods exhibit strength around $35 \mathrm{MPa}$. Table III shows the averaged data for all of the tests conducted ranging in duration from 24 to $500 \mathrm{hrs}$ at temperatures from 432 to $650^{\circ} \mathrm{C}$. This data is plotted in figure 4.

The data show that at lower temperatures longer exposure times are needed to achieve the strengthening effect. This type of behavior is common for diffusion based metallurgical changes (refs. 12 and 13). Abrupt phase transformations, such as the well known alpha to beta transformation that occurs for Zirconium Oxide, rapidly occur once a specific temperature threshold is exceeded (ref. 14). For the PS304 coating, the adhesion data suggests that more gradual changes occur which are enhanced by high temperatures and time. For instance, after exposure for $500 \mathrm{hr}$ at $482{ }^{\circ} \mathrm{C}$ the adhesion strength has only reached $\sim 2 / 3$ of full strength $(\sim 35 \mathrm{MPa})$. Yet at $650{ }^{\circ} \mathrm{C}$, a mere $24 \mathrm{hr}$ appears more than adequate to fully heat treat the PS304 coating. Several coating samples have been exposed for over $700 \mathrm{hr}$ at $650{ }^{\circ} \mathrm{C}$ and exhibit strengths around $35 \mathrm{MPa}$ suggesting that the strengthening effects have a terminus (reach a final value).

Many of the candidate substrates for PS304 are heat treated superalloys and stainless steels. Since a wide range of thermal exposure temperatures enhance coating strength it is likely that the coating thermal processing can be achieved coincidentally with a substrate heat treatment. In this case, the expense of an additional separate coating heat treatment could be avoided.

The adhesion data alone suggests diffusion controlled changes are occurring to the PS304 during the thermal processing. The observation that the strengthening occurs much more rapidly above $538{ }^{\circ} \mathrm{C}$ further indicates a solid state diffusion controlled effect. The main component in PS304 is $\mathrm{NiCr}$ which has a melting point of $1390{ }^{\circ} \mathrm{C}\left(1663^{\circ} \mathrm{K}\right)$. A heat treatment temperature of $538^{\circ} \mathrm{C}\left(811^{\circ} \mathrm{K}\right)$ is nearly 0.5 that of $\mathrm{NiCr}$ s melting point. In solid state diffusion, atomic mobility rates increase dramatically when the ambient temperature exceeds about 40 percent of the absolute melting point (ref. 12). Therefore, it is not surprising to observe what appears to be diffusion based property (adhesion strength) changes in the coating when exposed to temperatures above about $500{ }^{\circ} \mathrm{C}$.

Post heat treatment metallographic cross sections of the PS304 specimens help elucidate the reasons for the observed strength increase. Figures 5 and 6 show metallographic images, at various magnifications, of the PS304 coated stainless steel substrates at selected test temperatures and exposure times. The as deposited samples exhibit microstructural features typical for thermal spray coatings. The PS304 starts out as a powder blend of the individual constituents and each particle melts separately in the hot plasma and deforms upon impact with the substrate creating a layered coating structure made up of "splats" on top of one another. When examined under an optical microscope the different phases can be readily detected and identified. $\mathrm{The} \mathrm{NiCr}$ binder is predominant and bright, the silver is metallic and develops a slight tarnish, the chrome oxide is gray and the fluorides, when viewed with oblique lighting, appear transparent or slightly opaque. Black, nonreflective regions are porosity, which is typically about 15 percent of the structure. 
Since NiCr is PS304's major constituent its properties are likely to dominate the coating's properties, especially strength. Therefore, it is anticipated that changes to the $\mathrm{NiCr}$ matrix can have significant effects on the coating strength properties. The silver and fluorides are lubricant phases, therefore, any changes to these constituents, such as chemical reactions, degradation, or decomposition, are anticipated to have significant effects to the lubrication properties of the coating.

Examination of the coating cross sections reveals that the only readily observed change due to the thermal processing is an apparent phase segregation or, rather, second phase precipitation inside the $\mathrm{NiCr}$ binder regions. When PS304 deposited onto nickel based superalloys is heat treated a reaction layer forms at the interface. For PS304 deposited on stainless steel, no interfacial reaction layer is observed. The appearance of the silver, chrome oxide and fluoride phases remains unchanged even after exposure at $650{ }^{\circ} \mathrm{C}$ for over $100 \mathrm{hr}$. The $\mathrm{NiCr}$ phases, however, develop a striking microstructural feature which has the appearance of dark islands often locked inside $\mathrm{NiCr}$ particles. These regions, at first, were assumed to be some oxide phase. However, $\mathrm{NiCr}$ would be expected to develop an oxide passivating layer on its surface when exposed to air at high temperature not internal oxide phases. On the contrary, there does not appear to be any film or layer of oxide on the surface of the $\mathrm{NiCr}$ phases. In addition, the appearance of the "two phase" $\mathrm{NiCr}$ matrix is uniform throughout the coating. That is, its appearance is the same at the coating's outer surface which is directly exposed to air during the heat treatment and at the substrate interface which is well protected from the atmosphere. These observations suggest that during the heat treatment some type of diffusion driven second phase precipitation has occurred.

Scanning Electron Microscopic (SEM) analyses were conducted, coupled with Energy Dispersive X-Ray analyses (EDS), to elucidate the composition and nature of the changes to the $\mathrm{NiCr}$ matrix. The results are suggestive but not conclusive. For comparative purposes, an EDS spot spectrum of a $\mathrm{NiCr}$ area in an as deposited coating is shown in figure 7. The unheat treated $\mathrm{NiCr}$, which has an $80 / 20 \mathrm{wt} \%$ composition, exhibits a nickel to chromium peak height ratio of 6.2. Figure 8 shows EDS spot spectra of the $\mathrm{NiCr}$ matrix and its second phase precipitates. The dark, chromium rich precipitate phases are high in Chromium with smaller peaks of nickel and silicon. Oxygen and other species (fluorine, carbon barium, calcium etc.) are not detected. The $\mathrm{Ni} / \mathrm{Cr}$ ratio for the precipitate phase is about 0.5 . EDS spectra of the lighter surrounding $\mathrm{NiCr}$ matrix show large nickel content with a moderate chromium peak. When compared to the EDS spectra of as deposited $\mathrm{NiCr}$, the heat treated lighter phase appears somewhat Chromium depleted. The $\mathrm{Ni} / \mathrm{Cr}$ ratio in this case is about 10.2.

This comparison indicates that the Chromium concentration in the precipitated phase is a diffusion migration from the surrounding $\mathrm{NiCr}$ phase. The presence of silicon in the spectra is interesting. Silicon is not an intentional coating constituent. It is present as a ubiquitous additive in the $\mathrm{NiCr}$ powder produced commercially. Silicon, in the form of a silicate, is added to the $\mathrm{NiCr}$ powder as a powder flow enhancer. It is present at the 1 percent or less level and is often found in commercial thermal spray powders. The presence of a strong silicon peak in the precipitated phase suggests the formation of some type of Chromium-Silicon compound, perhaps a chrome silicide. Although not yet confirmed, coating thickness increases after heat treatment of up to about 3 percent have been observed and may be linked to the second phase precipitation.

The structure of both the dark precipitated phase and the surrounding $\mathrm{NiCr}$ matrix cannot be exactly determined using SEM/EDS techniques. Further analytical work using X-Ray diffraction and less complex (perhaps pure $\mathrm{NiCr}$ coatings) samples may be required to determine the true changes taking place during the heat treatments. It can be speculated, however, that during the heat treatment a chromium rich second phase precipitates inside the $\mathrm{NiCr}$ matrix leading to a strengthening effect. In addition, since the microstructure appears to be stable following the formation of the second phase, it is expected that the adhesion and strength properties of the PS304 coating will remain stable over longer periods. In fact, samples exposed to high temperature air for over seven hundred hours display adhesion properties and microstructures virtually indistinguishable from samples exposed for $24 \mathrm{hr}$ at $650^{\circ} \mathrm{C}$.

\section{CONCLUDING REMARKS}

The PS304 composite plasma sprayed coating exhibits an increase in adhesion strength of $\sim 100$ percent following exposure to temperatures above $500{ }^{\circ} \mathrm{C}$ for various lengths of time. The data shows that as the exposure temperature increased the time required to achieve strengthening dramatically decreased suggesting some type of diffusion controlled metallurgical change is occurring in the coating. Specimens exposed for long time periods at high temperatures do not experience any further increase in strength properties suggesting some type of metallurgical change occurs which reaches an equilibrium condition. Post test metallographic cross-sections coupled with SEM and EDS analyses indicate that a second phase, rich in chromium, precipitates in the $\mathrm{NiCr}$ matrix. The second phase, which appear as dark islands surrounded by a $\mathrm{NiCr}$ matrix, are often observed to contain silicon most likely coming from a silicate flow enhancer found in the $\mathrm{NiCr}$ powder feedstock. EDS 
elemental analysis shows that the $\mathrm{Ni}$ to $\mathrm{Cr}$ ratio in heat treated samples is lower than as deposited samples suggesting that the chromium in the second phase is coming from the $\mathrm{NiCr}$ matrix and not the chrome oxide constituent of PS304.

Preliminary measurements also indicate that a volume expansion of a few percent occurs following heat treatment. Similar to the adhesion strength, after the heat treatment is complete no further volume change occurs even after long exposure periods. These results indicate the need for a heat treatment of the PS304 coating after plasma spraying and prior to finish machining to insure dimensional stability and maximum adhesion properties. Further research is warranted to elucidate the exact nature of the coating changes that occur and to understand the possible effects, if any, of the substrate and environments on the performance and environmental durability of PS304.

\section{REFERENCES}

1. DellaCorte, C. and Edmonds, B.J.: "Preliminary Evaluation of PS300: A New Self-Lubricating High Temperature Composite Coating for Use to $800^{\circ} \mathrm{C}$," NASA TM-107056, November 1995.

2. DellaCorte, C.: "The Effect of Counterface on the Tribological Performance of a High Temperature Solid Lubricant Composite from 25 to $650^{\circ} \mathrm{C}$," NASA TM-107183, Surface, Coatings and Technology, 86-87 (1996), pp. 486-492.

3. DellaCorte, C. and Laskowski, J.A.: "Tribological Evaluation of PS300: A New Chrome Oxide Based Solid Lubricant Coatings Sliding Against $\mathrm{Al}_{2} \mathrm{O}_{3}$ from 25 to $650^{\circ} \mathrm{C}$," NASA TM-107163, Tribology Transactions, 1997.

4. DellaCorte, C. and Fellenstein, J.A.: "The Effect of Compositional Tailoring on the Thermal Expansion and Tribological Properties of PS300: A solid Lubricant Composite Coating," NASA TM-107332, Tribology Transactions, vol. 40 (1997), pp. 639-642.

5. DellaCorte, C.: "The Evaluation of a Modified Chrome Oxide Based High Temperature Solid Lubricant Coating for Foil Gas Bearings," NASA/TM-1999-208660, Tribology Transactions, vol. 43, pp. 257-262, April 2000.

6. DellaCorte, C., Valco, M.J., Radil, K.C. and Lukaszewicz, V.L.: "Performance and Durability of High Temperature Foil Air Bearings for Oil-Free Turbomachinery," NASA/TM-1999-209187, Tribology Transactions, October 2000.

7. Walther, G.C.: "Program for Plasma-Sprayed Self-Lubricating Coatings" NASA CR-3163, July 1979.

8. Howard, S.A.: "Rotordynamics and Design Methods of an Oil-Free Turbocharger," Tribology Transactions, vol. 42, no. 1, 1999, pp. 174-179.

9. Heshmat, H., Walton, J.F., DellaCorte, C. and Valco, M.J.: "Oil-Free Turbocharger Paves Way to Gas Turbine Engine Applications," ASME 2000-GT-620.

10. DellaCorte, C. and Sliney, H.E.: "Composition Optimization of Self-Lubricating Chromium Carbide Based Composite Coatings for Use to $760^{\circ} \mathrm{C}$," ASLE Transactions, vol. 30, no. 1, January 1987, pp. 77-83.

11. DellaCorte, C.: "Experimental Evaluation of Chromium Carbide Based Solid Lubricant Coatings for Use to $760^{\circ}, "$ NASA CR-180808, August 1987.

12. Shewmon, P.G.: "Diffusion in Solids," McGraw-Hill Book Company, pp. 175-179, 1963.

13. Boyer, H.E. and Gall, T.L.: "Metals Handbook, Desk Edition," chapter 28, pp. 64-78, American Society for Metals, 1985.

14. Kingery, W.D., Bowen, H.K. and Uhlmann, D.R.: "Introduction to Ceramics," John Wiley and Sons, Second Edition, 1975. 
TABLE I.-PS304 COMPOSITION

\begin{tabular}{|l|l|l|}
\hline Constituent & wt\% & \multicolumn{1}{|c|}{ Function } \\
\hline $\mathrm{NiCr}^{2}$ & 60 & binder \\
\hline $\mathrm{Cr}_{2} \mathrm{O}_{3}$ & 20 & hardener \\
\hline $\mathrm{Ag}$ & 10 & low temperature lubricant \\
\hline $\mathrm{BaF}_{2} / \mathrm{CaF}_{2}{ }^{b}$ & 10 & high temperature lubricant \\
\hline
\end{tabular}

${ }^{2} \mathrm{Ni} / \mathrm{Cr}$ ratio is $8 / 20$ by $w t \%$.

${ }^{\mathrm{b}} \mathrm{BaF}_{2} / \mathrm{CaF}_{2}$ ratio is $62 / 38$ by $w / \%$.

TABLE II -13-8 MO STAINLESS STEEL COMPOSITION

\begin{tabular}{|l|c|}
\hline \multicolumn{1}{|c|}{ Property } & Value \\
\hline Composition, wt\% & Fe-76, Cr-12.5, Ni-8.0, Mo-2.5, Al-1.0 \\
Density, g/cc & 7.8 \\
Ultimate tensile strength, MPa & 1480 \\
Yield strength. $\mathrm{MPa}$ & 1415 \\
Elastic modulus, GPa & 221 \\
Thermal expansion coefficient $/{ }^{\circ} \mathrm{C}$ & 11.0 \\
Thermal conductivity, W/m-k & 14 \\
Heat capacity, $\mathrm{J} / \mathrm{g}^{\circ} \mathrm{C}$ & 0.46 \\
\hline
\end{tabular}

TABLE III.-ADHESION DATA SUMMARY FOR PS304 DEPOSTTED ON 13.8 MO STAINLESS STEEL

\begin{tabular}{|c|c|c|c|}
\hline \multicolumn{2}{|c|}{ Heat treatment } & \multirow{2}{*}{\multicolumn{2}{|c|}{ Adhesion strength, $\mathrm{MPa}$, ksi }} \\
\hline $\begin{array}{c}\text { Temperature, } \\
{ }^{\circ} \mathrm{C}\end{array}$ & Time, hr & & \\
\hline \multicolumn{2}{|c|}{ None as-deposited coating } & $(17.2 \pm 1.2)$ & $25.1 \pm 4.3$ \\
\hline 482 & 75 & $(17.7 \pm 03)$ & $26.4 \pm 1.6$ \\
\hline 482 & 150 & $(22.8 \pm 1.1)$ & $33.9 \pm 1.6$ \\
\hline 482 & 250 & $(20.2 \pm 1.3)$ & $30.0 \pm 2.0$ \\
\hline 482 & 500 & $(22.8 \pm 2.0)$ & $34.0 \pm 3.0$ \\
\hline 538 & 100 & $(20.2 \pm 3.4)$ & $30.0 \pm 5.0$ \\
\hline 538 & 150 & $(32.5 \pm 3.3)$ & $48.3 \pm 4.9$ \\
\hline 538 & 200 & $(30.2 \pm 3.4)$ & $45.0 \pm 5.0$ \\
\hline 538 & 500 & $(36.6 \pm 1.4)$ & $54.5 \pm 2.0$ \\
\hline 593 & 25 & $(28.8 \pm 8.1)$ & $42.9 \pm 1.2$ \\
\hline 593 & 50 & $(35.9 \pm 0.7)$ & $53.5 \pm 1.0$ \\
\hline 593 & 100 & $(37.4 \pm 1.0)$ & $55.6 \pm 1.5$ \\
\hline 593 & 150 & $(34.4 \pm 1.4)$ & $51.2 \pm 2.0$ \\
\hline 593 & 200 & $(37.5 \pm 1.2)$ & $55.8 \pm 1.5$ \\
\hline 650 & 25 & $(33.3 \pm 0.7)$ & $49.5 \pm 1.0$ \\
\hline 650 & 50 & $(31.2 \pm 0.7)$ & $46.5 \pm 1.0$ \\
\hline 650 & 100 & $(33.9 \pm 1.5)$ & $50.5 \pm 2.0$ \\
\hline 650 & 150 & $(32.4 \pm 1.8)$ & $48.2 \pm 2.2$ \\
\hline 650 & 200 & $(36.5 \pm 1.2)$ & $54.3 \pm 1.7$ \\
\hline
\end{tabular}




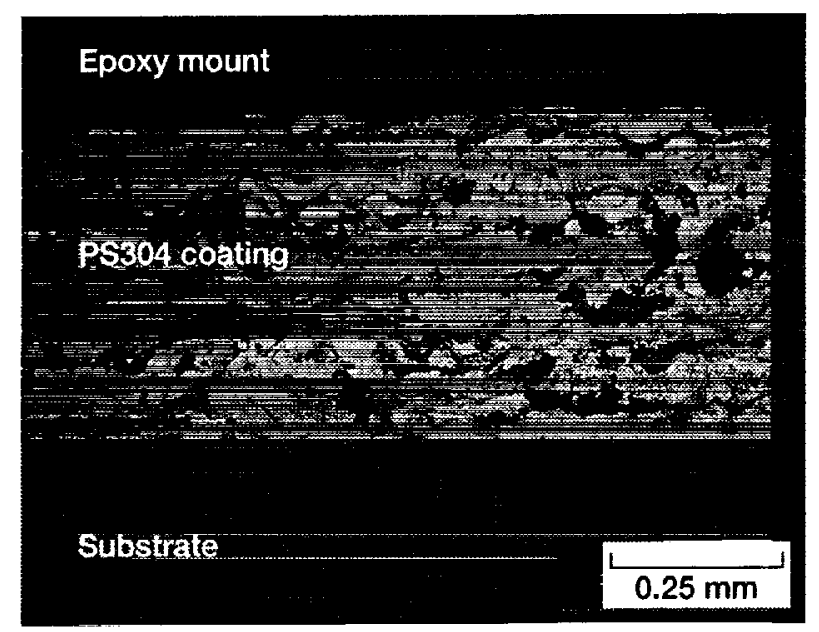

Figure 1.-Cross-section photomicrograph of an asdeposited PS304 coating on a 13-8 Mo stainless steel substrate.
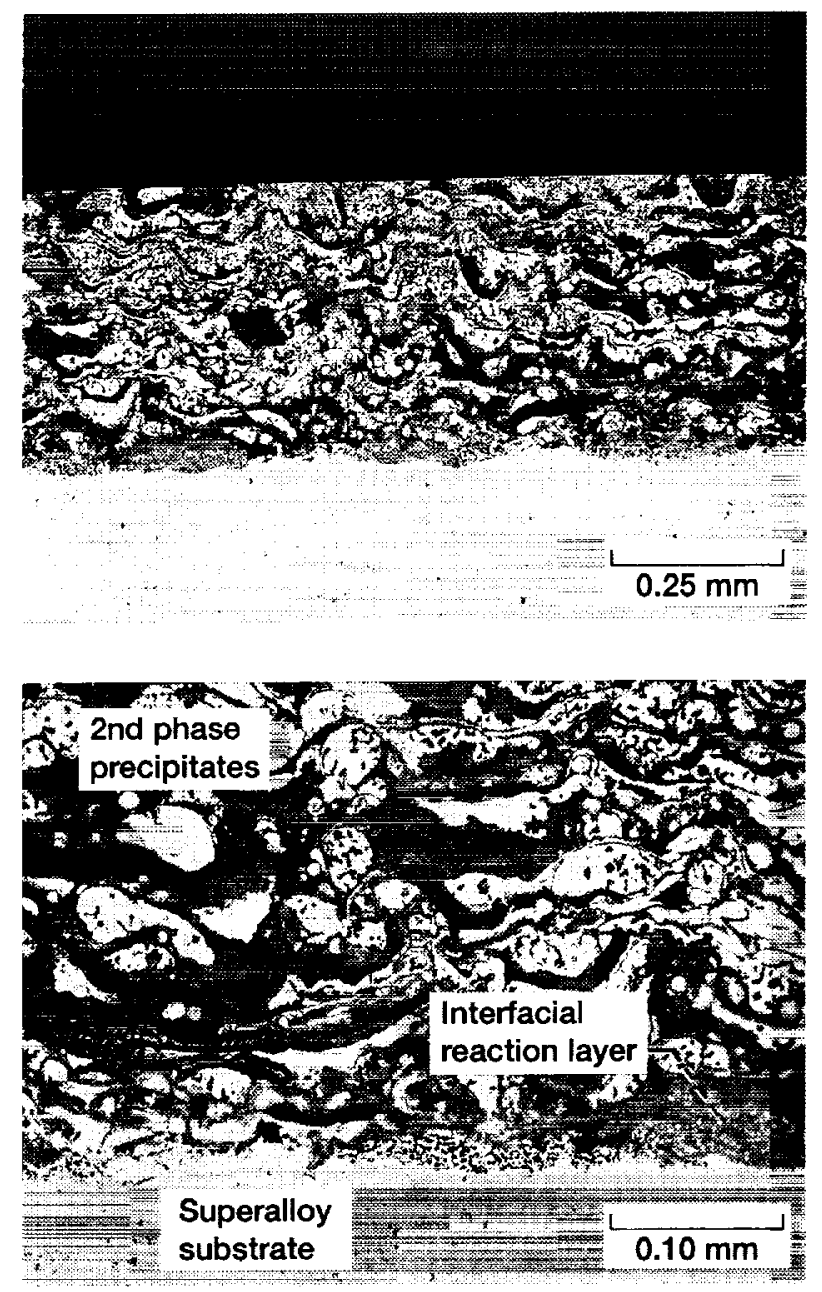

Figure 2.-Cross-section photomicrographs of PS304 coating deposited on a nickel based superalloy substrate after exposure in air at $650^{\circ} \mathrm{C}$ for $700 \mathrm{hr}$. Note interfacial reaction layer and second phase precipitates in NiCr matrix. 


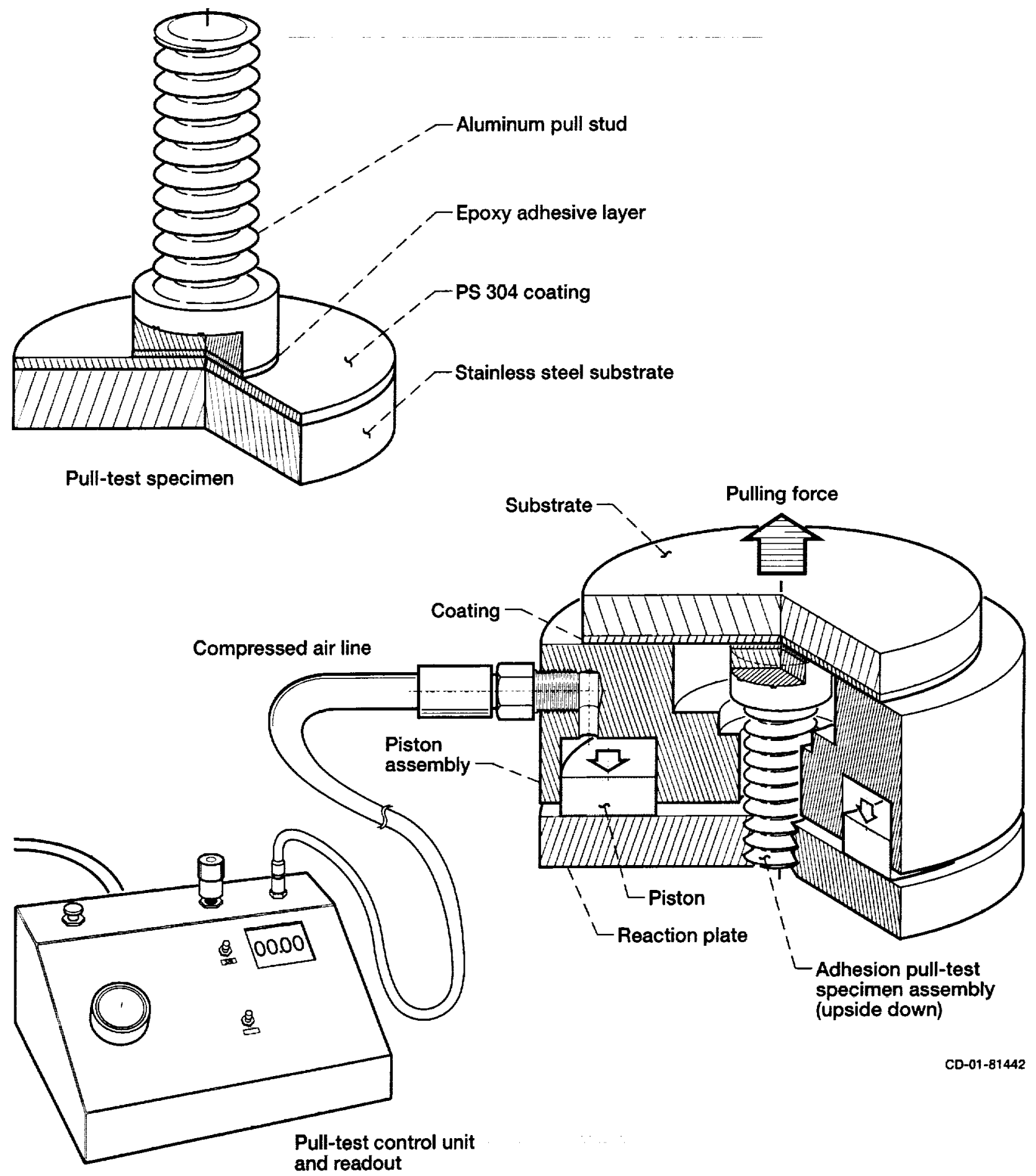

Figure 3.-Adhesion pull-test specimen assembly and system. 


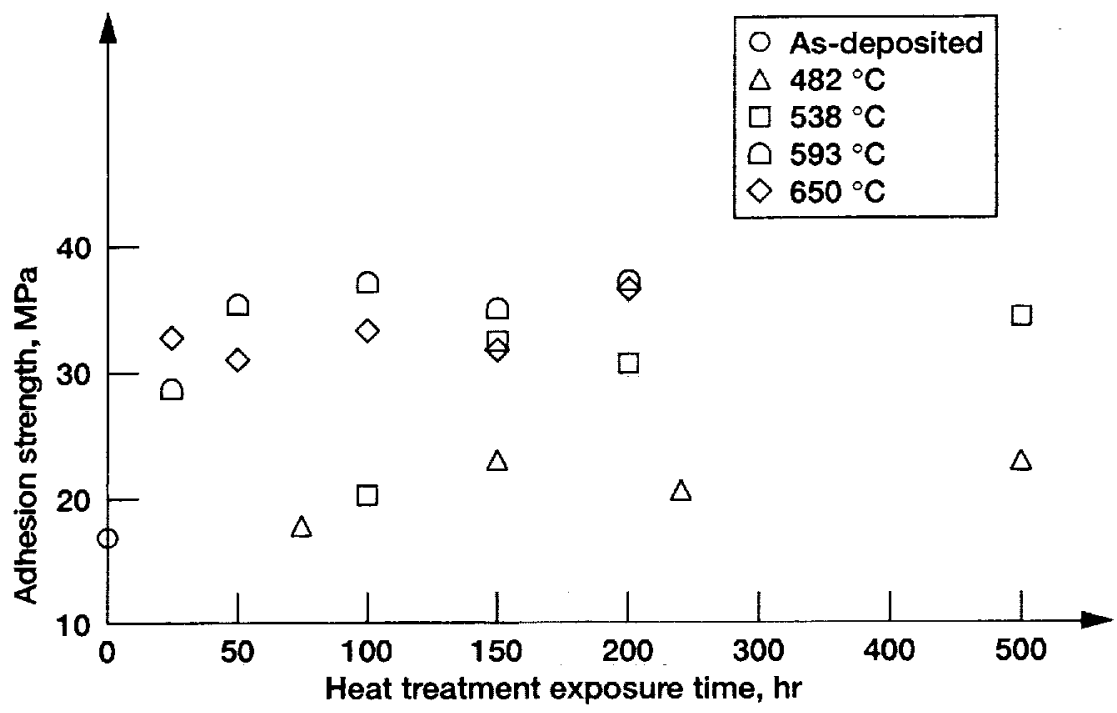

Figure 4.-Adhesion strength versus exposure time at various temperatures for PS304 deposited on 13-8 Mo stainless.
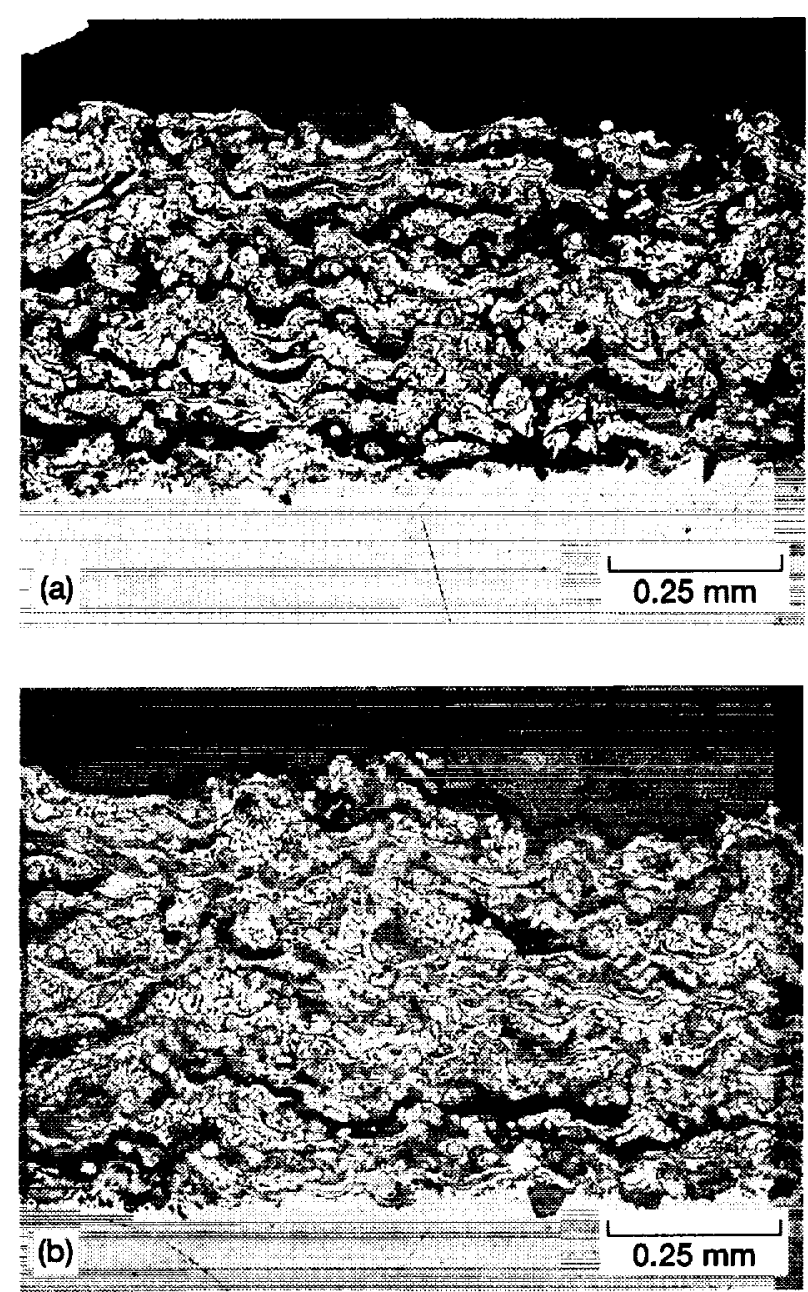

Figure 5.-Cross-section photomlcrographs of PS304 exposed in air for 150 hours. (a) $593^{\circ} \mathrm{C}$. (b) $650^{\circ} \mathrm{C}$. 

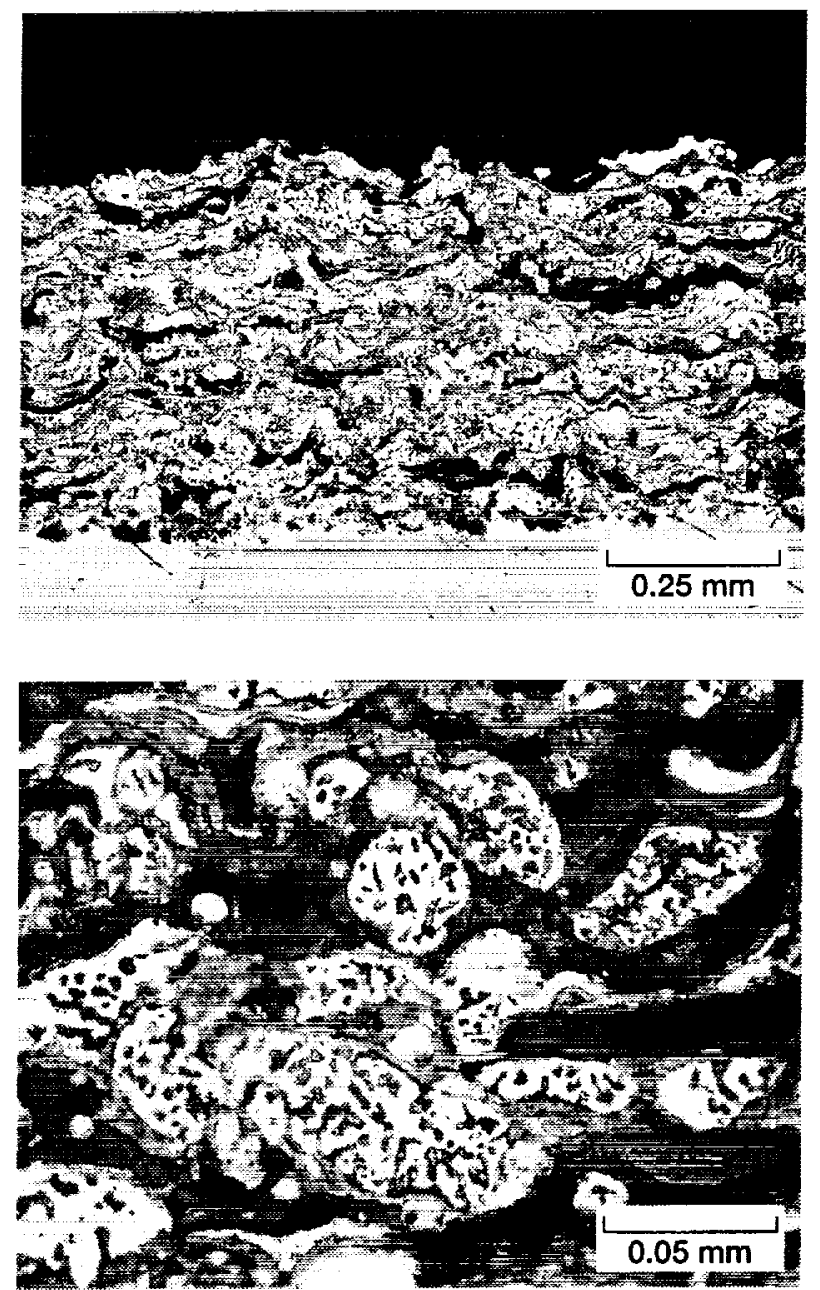

Figure 6.-Cross-section photomicrographs of PS304 after exposure in air at $650^{\circ} \mathrm{C}$ for $50 \mathrm{hr}$.

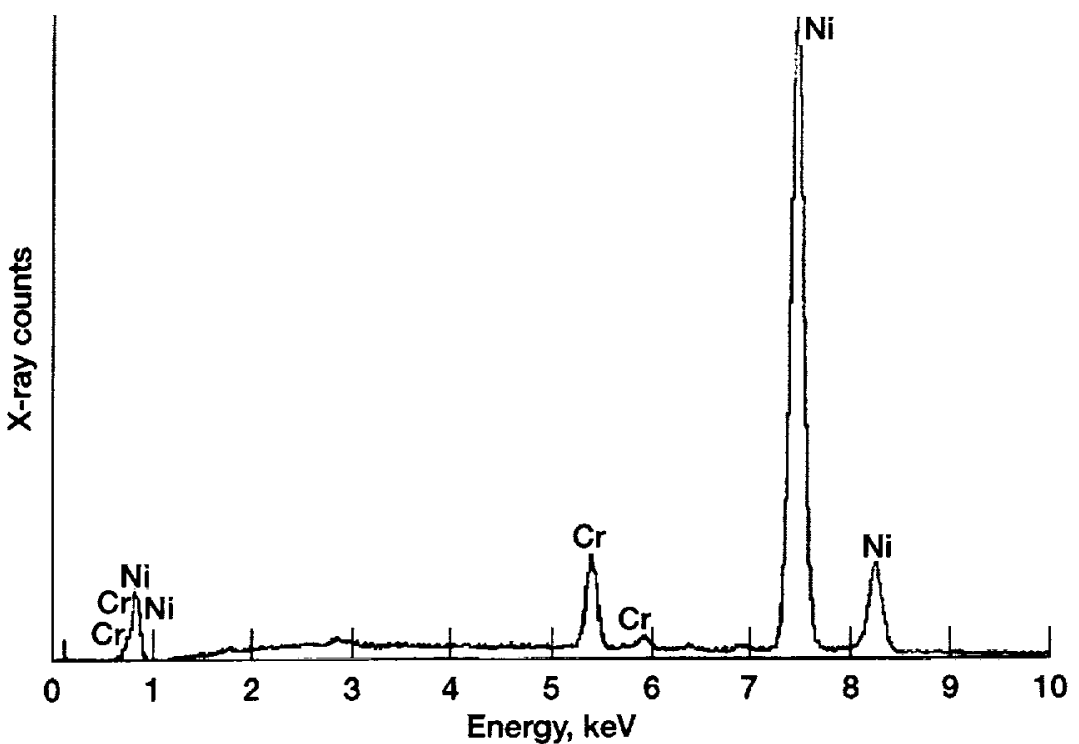

Figure 7.-EDS spectra of NiCr matrix phase of PS304 as deposited coating. $\mathrm{Ni} / \mathrm{Cr}$ peak height ratio is $\approx 6.2$. 


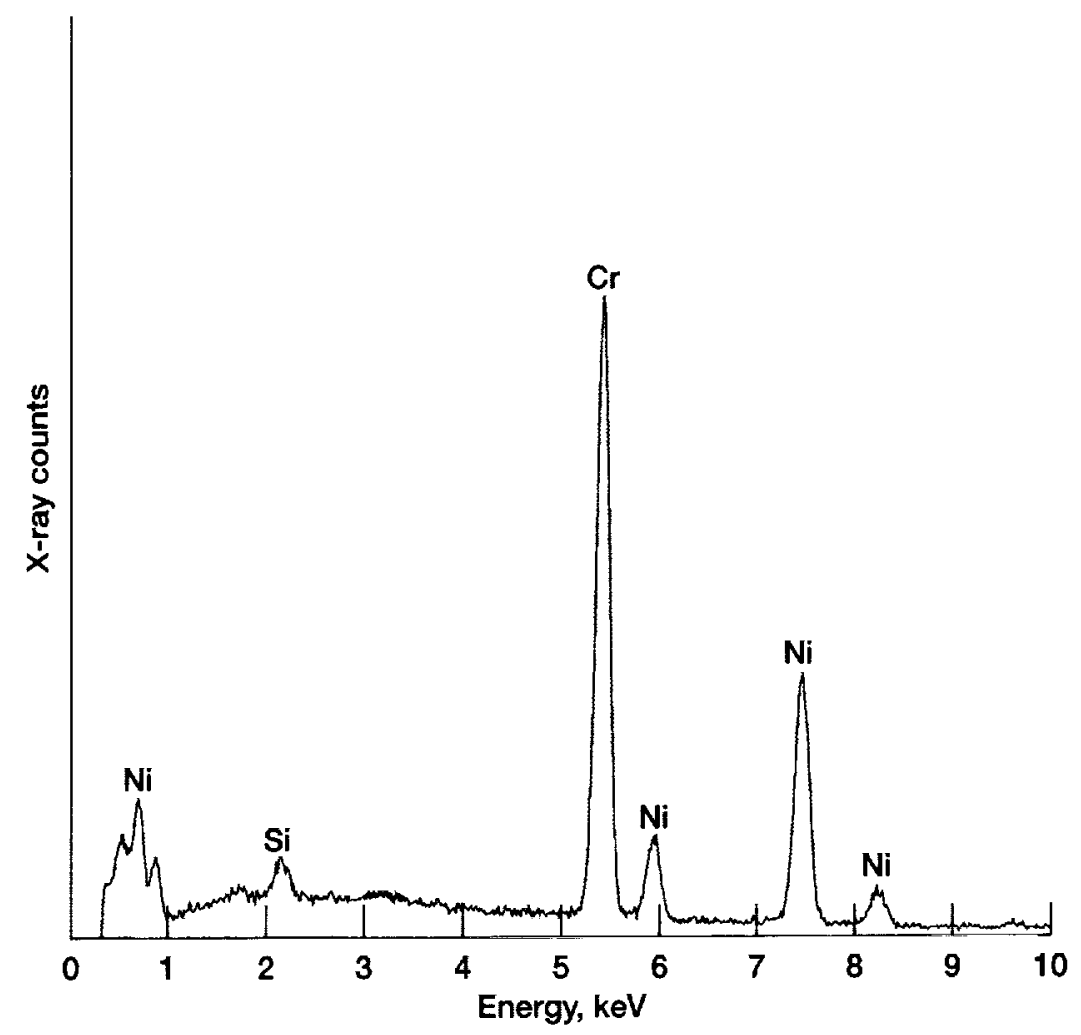

Figure 8.-EDS spectra of dark chromium rich precipitate inside $\mathrm{NiCr}$ matrix phase of PS304 exposed at $650{ }^{\circ} \mathrm{C}$ for 150 hours. Ni/Cr peak height ratio is $\approx 0.5$.

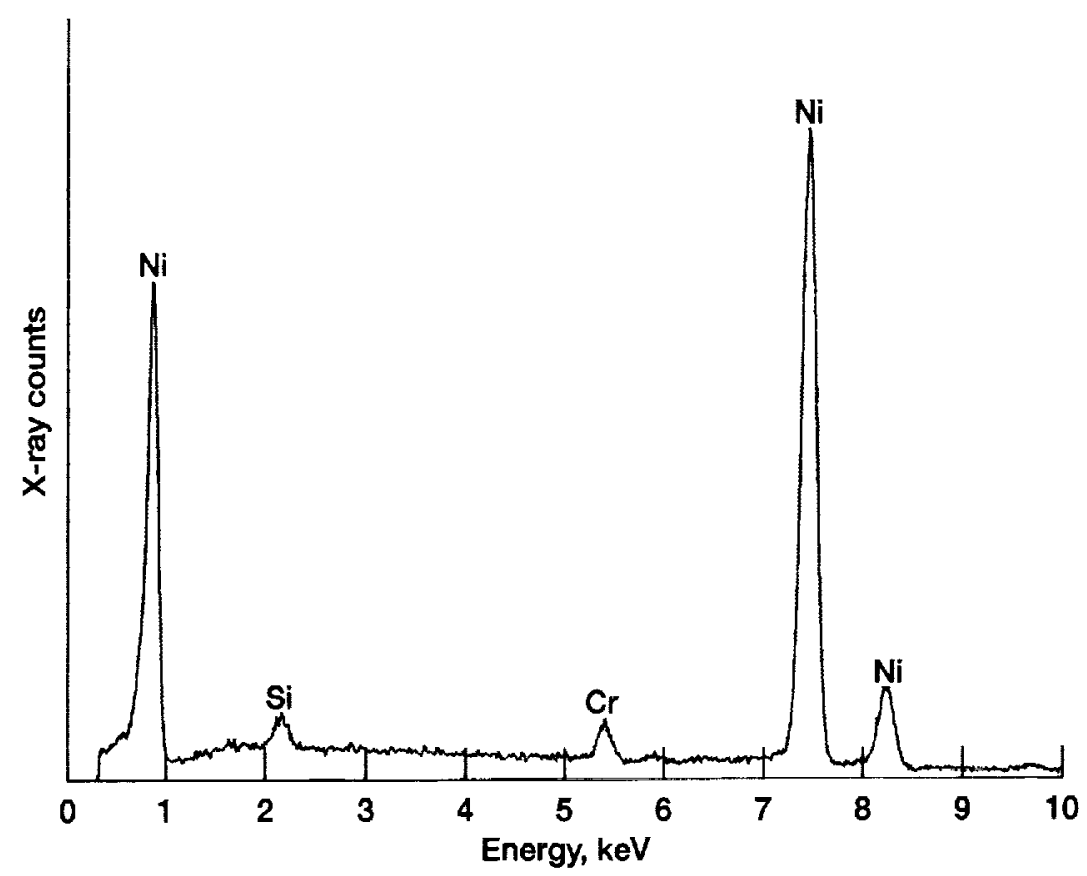

Figure 9.-EDS spectra of $\mathrm{NiCr}$ phase surrounding dark chromium rich precipitate from PS304 exposed at $650^{\circ} \mathrm{C}$ for 150 hours. Note apparent depletion of chromium content. $\mathrm{Ni} / \mathrm{Cr}$ peak height ratio is $\approx 10.6$. 
Public reporting burden for this collection of information is estimated to average 1 hour per response, including the time for revlewing instructions, searching existing data sources, gathering and maintaining the data needed, and completing and reviewing the collection of information. Send comments regarding this burden estimate or any other aspect of this
colfection of information, including suggestions for reducing this burden, to Washington Headquarters Services, Directorate for Information Operations and Reports, 1215 Jefferson Davis Highway, Suite 1204, Arlington, VA 22202-4302, and to the Office of Management and Budget, Paperwork Reduction Project (0704-018B), Washington, DC 20503.

\begin{tabular}{|l|l|l}
\hline 1. AGENCY USE ONLY (Leave blank) & $\begin{array}{c}\text { 2. REPORT DATE } \\
\text { May } 2001\end{array}$ & $\begin{array}{r}\text { 3. REPORT TYPE AND DATES COVERED } \\
\text { Technical Memorandum }\end{array}$
\end{tabular}

\section{TITLE AND SUBTITLE}

Thermal Processing Effects on the Adhesive Strength of PS304 High Temperature Solid Lubricant Coatings

6. AUTHOR(S)
5. FUNDING NUMBERS

WU-708-18-13-00

Christopher DellaCorte, Brian J. Edmonds, and Patricia A. Benoy

7. PERFORMING ORGANIZATION NAME(S) AND ADDRESS(ES)

National Aeronautics and Space Administration

John H. Glenn Research Center at Lewis Field

Cleveland, Ohio 44135-3191

8. PERFORMING ORGANIZATION

REPORT NUMBER

E-12798

9. SPONSORING/MONITORING AGENCY NAME(S) AND ADDRESS(ES)

National Aeronautics and Space Administration

Washington, DC 20546-000I

10. SPONSORING/MONITORING

AGENCY REPORT NUMBER

NASA TM-2001-210944

11. SUPPLEMENTARY NOTES

Christopher DellaCorte and Brian J. Edmonds, NASA Glenn Research Center; and Patricia A. Benoy, St. Louis University, St. Louis, Missouri 63103. Responsible person, Christopher DellaCorte, organization code 5960, 216-433-6056.

\section{2a. DISTRIBUTION/AVAILABILITY STATEMENT}

12b. DISTRIBUTION CODE

Unclassified - Unlimited

Subject Category: 23

Distribution: Nonstandard

Available electronically at http://gltrs.grc.nasa.gov/GLTRS

This publication is available from the NASA Center for AeroSpace Information, 301-621-0390.

13. ABSTRACT (Maximum 200 words)

In this paper the effects of post deposition heat treatments on the cohesive and adhesive strength properties of PS304, a plasma sprayed nickel-chrome based, high temperature solid lubricant coating deposited on stainless steel, are studied. Plasma spray deposited coating samples were exposed in air at temperatures from 432 to $650^{\circ} \mathrm{C}$ for up to $500 \mathrm{hr}$ to promote residual stress relief, enhance particle to particle bonding and increase coating to substrate bond strength. Coating pull off strength was measured using a commercial adhesion tester that utilizes $13 \mathrm{~mm}$ diameter aluminum pull studs attached to the coating surface with epoxy. Pull off force was automatically recorded and converted to coating pull off strength. As deposited coating samples were also tested as a baseline. The as-deposited (untreated) samples either delaminated at the coating-substrate interface or failed intemally (cohesive failure) at about $17 \mathrm{MPa}$. Samples heat treated at temperatures above $540^{\circ} \mathrm{C}$ for $100 \mathrm{hr}$ or at $600^{\circ} \mathrm{C}$ or above for more than $24 \mathrm{hr}$ exhibited strengths above 3 I MPa, nearly a two fold increase. Coating failure occurred inside the body of the coating (cohesive failure) for nearly all of the heat-treated samples and only occasionally at the coating substrate interface (adhesive failure). Metallographic analyses of heat-treated coatings indicate that the NickelChromium binder in the PS304 appears to have segregated into two phases, a high nickel matrix phase and a high chromium precipitated phase. Analysis of the precipitates indicates the presence of silicon, a constituent of a flow enhancing additive in the commercial $\mathrm{NiCr}$ powder. The exact nature and structure of the precipitate phase is not known. This microstructural change is believed to be partially responsible for the coating strength increase. Diffusion bonding berween particles may also be playing a role. Increasing the heat treatment temperature, exposure time or both accelerate the heat treatment process. Preliminary measurements indicate that the heat treatment also results in a one time, permanent coating thickness increase of about 3 percent. Based upon these results, the incorporation of a heat treatment prior to final finishing has been incorporated in the application process of this coating technology.

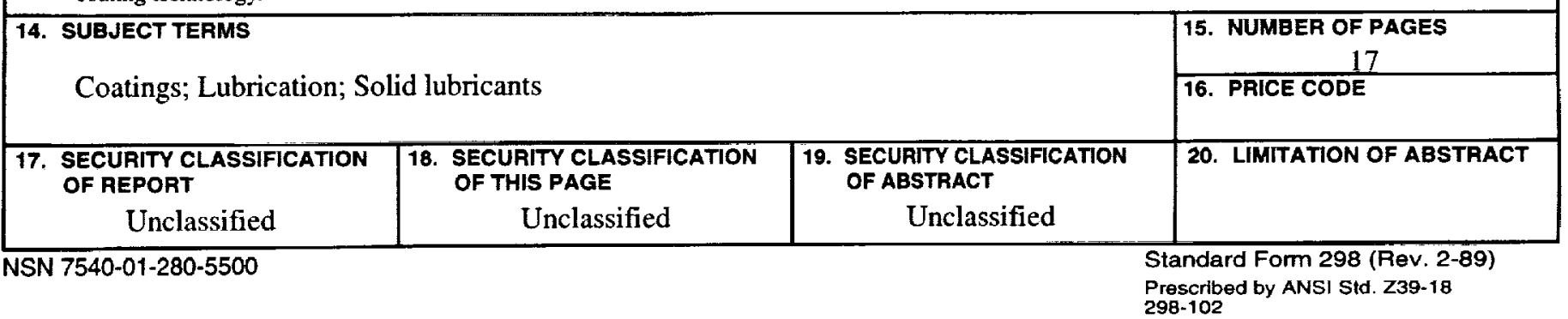

